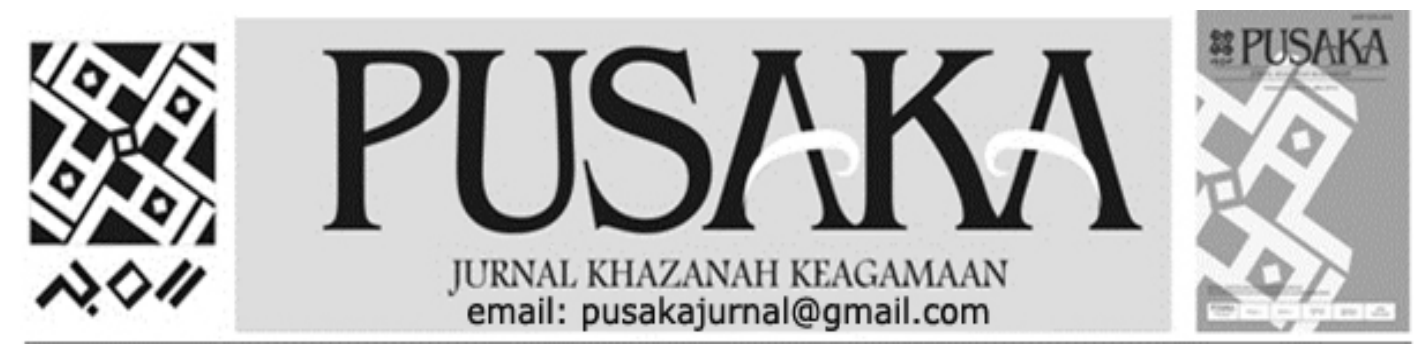

Menyingkap Yang Terselubung

(Catatan Perjalanan Perburuan Naskah Klasik Keagamaan Kabupaten Tidore Kepuluan, Maluku Utara)

\title{
Revealing the Covert
}

(The Field Note Hunting of Religious Manuscript at Tidore, North Maluku)

\section{Idham}

Balai Penelitian dan Pengembangan Agama Makassar

J1.A.P.Pettarani No.72 Makassar. Telp:0411-452952

Email: idbodi@yahoo.co.id

\begin{tabular}{|c|c|}
\hline $\begin{array}{c}\text { Info } \\
\text { Artikel }\end{array}$ & Abstract \\
\hline $\begin{array}{c}\text { Diterima } \\
2 \\
\text { Juni } \\
2017 \\
\text { Revisi I } \\
1 \\
\text { Agustus } \\
2017\end{array}$ & $\begin{array}{l}\text { Tulisan ini merupakan catatan perjalanan penelitian awal tentang pemetaan dan } \\
\text { digitalisasi naskah klasik keagamaan. Penelitian awal dimaksudkan untuk } \\
\text { mengetahui layak tidaknya suatu menelitian. Penelitian pada Balai Penelitian dan } \\
\text { Pengambangan Agama Makassar dilakukan dalam beberapa tahapan, yakni: } \\
\text { penentuan judul yang diverifikasi oleh peneliti utama, pembahasan Desain } \\
\text { Operasional (DO), pembahasan Instrumen Pengumpulan Data (IPD). Apabila } \\
\text { semuanya sudah dianggap bagus, langkah selanjutnya adalah penjajakan awal } \\
\text { (peneitian awal) untuk menengetahui layak tidaknya penelitian itu diadakan di } \\
\text { daerah tersebut. Penentuan layak tidaknya tersebut ditentukan dalam seminar } \\
\text { (seminar awal). Penjajakan awal ini diadakan sekitar delapan hari, dan selanjutnya } \\
\text { diadakan pengumpulan data penelitian selama delapan belas hari. Adapun yang ada } \\
\text { dalam tulisan ini adalah catatan penelitian awal penulis. Pengumpulan data } \\
\text { dilakukan dengan observasi, wawancara, dan dokumentasi. Gaya penulisan } \\
\text { dilakukan secara mengalir apa adanya. Penelitian awal sangat berguna untuk } \\
\text { pengumpulan data penelitian selanjutnya. Banyak peristiwa yang tidak diprediksi } \\
\text { sebelumnya, bahkan pemburuan data di lapangan banyak yang tidak ada atau tidak } \\
\text { sesuai dengan metodde-metode dalam buku-buku metode penelitian, jadi perlu } \\
\text { kelihaian dan keahlian peneliti dalam mengumpulkan data yang diperlukan. } \\
\text { Kata Kunci: Naskah Klasik, Catatan Perjalanan }\end{array}$ \\
\hline $\begin{array}{c}\text { Revisi II } \\
25 \\
\text { September } \\
2017\end{array}$ & $\begin{array}{l}\text { This paper is a record of a preliminarv research trip on mapping and digitizing } \\
\text { religious manuscripts. Initial research is intended to find out whether or not a } \\
\text { research is feasible. Research on Islamic Research and Research Institute of } \\
\text { Makassar is done in several stages, namelv: the determination of titles verified bv } \\
\text { the principal investigator, the discussion of Operational Design (DO). discussion } \\
\text { of Data Collection Instrument (IPD). If evervthing is considered good. the next } \\
\text { step is to preliminarv (initial assessment) to find out whether or not the research } \\
\text { was conducted in the area. The determination of whether or not is determined in } \\
\text { the seminar (initial seminar). This initial assessment was held for about eight davs. } \\
\text { and then the eighteen davs of research data was collected. As for what is in this } \\
\text { paper is the author's initial research note. Data collection is done bv observation, } \\
\text { interview. and documentation. Writing stvle is done flowing as is. Initial research } \\
\text { is verv useful for further research data collection. Manv unpredictable events, even } \\
\text { field hunts are either missing or inconsistent with methodologies in research } \\
\text { methods books, so it is necessary for researchers' skill and expertise in collecting } \\
\text { the necessary data. } \\
\text { Keywords: Manuscripts, Field Notes }\end{array}$ \\
\hline
\end{tabular}




\section{PENDAHULUAN}

Pada Awal Februari 2017, semua peneliti di lingkungan Balai Penelitian dan Pengembangan Agama Makassar dan sebahagian besar staf turun lapangan dalam rangka penjajakan dan penelitian awal berdasarkan judul masingmasing bidang. Kami di bidang Lektur dan Khazanah Keagamaan, pada penelitian tahap pertama ini mengangkat dua tema penelitian, yakni Jaringan Ulama di Sulawesi Selatan dan Katalogisasi Naskah Klasik Keagamaan. Khusus tema katalogisasi naskah terbagi atas dua tim, yakni Tim Sulawesi Selatan dengan penelitinya Muhammad Subair dan Lamansi. Adapun Tim Maluku Utama dengan penelitinya Idham, Abu Muslim dan Muhammad Sadli Mustafa. Alhamdulillah dalam penjajakan lapangan ini kami dibantu dua orang staf yang cukup dapat diandalkan, yakni Amru Ichwan Alwy dan Muhammad Nur.

Beberapa peneliti sepakat berkumpul di kantor untuk menuju bandara. Penerbangan dengan Garuda kali ini berbarengan dengan peneliti bidang lain yang akan melakukan juga penjajakan di Manado dan Maluku Utara. Kami peneliti dari Litbang Agama Makassar cukup banyak, yang singgah di Manado empat orang (peneliti dan staf), dan kami yang melanjutkan perjalanan ke Maluku Utara berjumlah sembilan orang, empat orang peneliti Bidang Kehidupan Keagamaan, dan lima orang Biidang Lektur dan Khazanah Keagamaan.

Di atas pesawat, kami duduk tidak terlalu berjauhan. Kami masih bisa bercanda dengan sesama peneliti.

Alhamdulillah,

pemberangkatan pagi hari cuaca cukup bagus. Perjalanan dari Makassar ke Manado hanya ditempuh sekitar 90 menit. Kami peneliti di Maluku Utara dan peneliti di Manado berpisah di Bandara Sam Ratulagi Manado. Hanya ucapan selamat kepada teman-teman yang bertugas di Manado, dan kami harus melanjutkan perjalanan ke Maluku Utara, kami hanya transit sekitar 15 menit. Perjalanan udara dari Manado ke Ternate akan ditempuh sekitar 40 menit. Cuaca cukup cerah. Kami dapat melihat beberapa pulau, termasuk pulau Tidore dan Maitara yang pernah kami jelajahi dua tahun yang lalu. Tidak berselang lama, kami sudah melihat telaga, ini berarti kami sudah di atas pulau Ternate. Akhirnya kami mendarat dengan mulus di Bandara Babullah Ternate.

Ternate dan Tidore, di samping kerajaan Bacan dan Jailolo di Maluku Utara adalah empat kerajaan besar pada zamannya. Empat kerajaan ini juga disebut KieRaha, sesuai perjanjian di Pulau Moti. Dalam hal penaskahan, tiga kerajaan dari empat kerajaan tersebut sudah pernah dijelajah oleh tim naskah dari Balitbang Agama Makassar, mines kerajaan Jailolo. Pulau Ternate sudah pernah dijelajah oleh Muhammad As'ad dan Idham di Tahun 2009. Namun tak ada satupun naskah yang ditemukan pada masyarakat. Hanya ada tiga buah Alqur'an tulisan tangan yang ditemukan di Museum/kedaton Ternate. Selanjutnya, penjelajahan naskah dilanjutkan di Tidore pada tahun 2010 oleh Idham dan Abu Muslim, dan tahun 2011 dilanjutkan kembali di Pulau Tidore oleh Idham, La Sakka, Abu Muslim, dan La 
Mansi. Di Tahun yang sama (2011), tim Abu Muslim bersama La Mansi melanjutkan penjelajahan ke Kerajaan Bacan. Akan tetapi di Bacan, tim ini hanya menemukan satu naskah klasik keagamaan.

Dari Bandara Babullah kami mencarter dua mobil bandara untuk mengantar kami ke Hotel Archi, hotel yang kami sudah pesan sebelumnya. Hotel ini berada di Jalan Nuku, dekat pantai Palajawa. Tidak ada aktivitas kami hari ini. Antara tim lektur dan tim kehidupan bersepakat bahwa untuk mengefektifkan kerja tim, maka yang mengurus izin dan administrasi lainnya dibebankan ke pendamping peneliti Bidang Kehidupan, karena pendamping Bidang Lektur pada keesokan harinya akan langsung menuju sasaran penjelajahan naskah, Pulau Tidore.

Setelah kami sarapan, kami berlima tim Naskah bersiap-siap ke Pulau Tidore. Ke Pulau Tidore harus melalui pelabuhan Bastiong di Ternate. Pulau Ternate dan pulau Tidore cukup berdekatan, hanya diantarai oleh selat yang apabila naik speed, hanya ditempuh 5-7 menit saja. Untuk mengefektifkan waktu, kami mencarter oto (mobil angkutan) untuk mengantarkan kami ke pelabuhan Bastiong. Pelabulan Bastiong sudah ramai, banyak para nahkoda yang menawarkan perahu speednya. Namun kami lebih memilih untuk naik speed umum, selain harga yang lebih murah dibandingkan bila dicarter, naik speed umum juga kami dapat memperoleh informasi atau berkenalan dengan masyarakat dalam perjalanan.
Palabuhan Bastiong hari itu cukup cerah, ombak pun tenang. Masyarakat di pelabuhan beraktifitas sesuai profesi masing-masing, cukup ramai. Diantara kami ada yang makan siang sebelum berangkat naik speed dan yang lainnya ada yang masih merasa kenyang. Teman yang merasa kenyang harus beli nasi bungkus, karena kami yakin di Tidore, tempat kami menginap nantinya, sulit menemukan penjual nasi. Bila kami mau makan harus pergi ke pasar yang jaraknya cukup jauh. Selain itu, kami pun membeli buah tangan untuk "panglima" kami.

Panglima adalah sebutan orang yang selama ini membantu kami dalam pencarian naskah. Dari sang panglima-lah kami dapat memasuki setiap sudut naskah di Tidore. Gelar panglima ini sebenarnya kami yang memberikannya. Beliau bernama Muhiddin, Imam Jawa Turu'. Pak Muhiddin merupakan salah satu guru tharikat yang diwarisi secara turun temurun dari orangtua dan kakek buyutnya. Maka tidak salah setiap kami berkunjung ke rumah muridmurid dan keluarganya, tuan rumah dan keluarganya akan datang menyalami sang guru, berjabat tangan dan tidak akan berpindah sebelum sang guru memegang ubunubun orang yang disalaminya. Selain itu, menurut cerita masyarakat, beliau juga yang membuatkan jimat, berupa kain putih yang sudah dijampi kemudian diikatkan di lengan pada saat konflik Maluku yang lalu. Siapapun yang sudah diikatkan kain putih, orang tersebut punya keberanian untuk berlaga di medan perang, karena akan tidak termakan oleh besi. 
Setelah semua selesai, kami naik speed bersama dengan penumpang (masyarakat) yang lainnya. Ombak cukup tenang karena belum sore, baru setengah jam 12 siang. Dengan ceria, kami menuruni tangga pelabukan untuk masuk ke dalam speed. Setelah semuanya duduk, nahkoda kapal membunyikan mesin. Mesin pertama sudah menyala dan lambat laun speed pun bergerak maju. Namun untuk menyalakan mesin kedua, disini ada kendala, mesin kedua tak dapat hidup dan tiba-tiba mesin pertama pun mendadak mati. Berselang beberapa menit, kedua mesin tak dapat dihidupkan. Para penumpang sudah was-was, saat mesin mati, goncangan speed sangat terasa. Salah seorang penumpang berteriak 'kembali saja'. Kami hanya diam, mana mungkin kami kembali ke pelabuhan Bastiong? Kan mesin speed tidak bisa bunyi. Nahkoda kapalpun bertepuk tangan sambil berteriak ke darat, tapi semua sia-sia. Sekitar 10 menit kami terobang-ambing tanpa kepastian, gelombang pun semakin besar, kini air ombak masuk ke dalam speed bagian belakang, salah saorang ibu-ibu yang duduk dekat mesin terkena hempasan ombak, "basa e, pulang sudah" kata ibu tersebut. Dengan santai sang nahkoda berkata: "tidak apa-apa bu". "apa tidak apa-apa, so kita basa", ibu menjawab dengan nada jengkel. Saat air masuk speed, dua tiga gadis yang duduk di bagian tengah teriak histeris. Teriakan histeris inilah yang manambah ketegangan kami. Penduduk setempat saja ketakutan, apalagi kami yang tak terbiasa naik speed seperti ini.
Salah seorang tim kami pun ada yang takut dengan air, katanya pernah trauma hanyut di sungai. Teman kami pun menjadi tumpuan mata kami, memang dia gemetaran, pucat tak bisa berkata kata, walaupun kami tengang tapi ada yang lebih tengang dari kami. Sambil memperhatikan letak palampung, namun pelampung berada di bagian paling depan. Namun dalam ketengangan itu, salah seorang diantara tim kami ternyata ada yang masih sempat merekam kejadian tersebut. Sekitar 15 menit kami terombang ambing di atas lautan, alhamdulillah ada speed yang kembali dari Tidore dan bersedia membantu kami. Kami semua pindah speed untuk menuju pelabuhan Rum, pulau Tidore.

Walaupun kami sudah pindah speed, akan tetapi was-was tetap menghantui kami. Tak ada canda dan tawa di speed yang baru. Semua penumpang terdiam. Perjalanan ke Tidore yang hanya ditempuh sekitar tujuh menit begitu terasa. Akhirnya kamipun sampai juga di pelabuhan Rum. Kondisinya masih seperti dulu dua tahun yang lalu saat saat kami datang dengan tujuan sama. Di pelabuhan Rum, para supir angkot dan mobil carteran banyak mengerumuni kami menawarkan jasa. Kami menolak mereka, karena kami sudah ada langgganan yang sudah dikontak sejak pagi hari. Dari jauh, supir mobil yang kami pesan sudah melambaikan tangan, supir sekaligus pemilik mobil itu adalahl pak Dar. Beliau adalah orang Toloa, yang mana pada dua tahun yang lalu beliaulah yang mengantar kami mengelilingi Pulau Tidore mencari naskah, bahkan bersedia mengantar 
kami ke puncak pulau gunung Tidore, desa gurabunga.

Cuaca Tidore cukup panas di hari itu, untung mobil yang kami tumpangi ber-AC, kami tetap sejuk. Canda dan tawa sangat cair di antara kami. Sepanjang jalan kami membicarakan kejadian di atas speed yang baru saja kami lalui. Selain itu, kami sangat menikmati pemandangan laut, pulau dan gunung. Sangat menakjubkan, ditambah lagi Tidore yang sangat bersih, langganan adipura.

Tak terasa, sekitar 40 menit, kami sampai di Soasio, kota lama, ibukota kerajaan Tidore. Disini hanya ada satu penginapan, penginapan Seroja. Penginapan ini begitu akrab bagi peneliti, ini kali keempat kami ke sini. Kami memilih Seroja karena aksesnya cukup mudah. Di sekitar ini juga banyak pemilik naskah. Penginapan Seroja, sekilat seperti rumah penduduk, dan memang rumah penduduk yang disulap jadi penginapan. Rumah ini dulunya adalah rumah mantan gubernur pertama Papua, Zainal Abidin. Penginapan itu diwariskan kepada kelurganya yang bernama Ibu Salma yang sudah tua, berumur 80 an tahun. Dengan hangat ia menyambut kami. Penginapan ini selalu full, untung masih ada dua kamar yang kosong. Kami pun beristirahat karena ba'da ashar akan bertemu panglima dalam rangka mengatur jadwal penjelajahan naskah.

Rumah Muhyiddin, sang panglima sekitar 150 meter dari penginapan Seroja, arah kadara. Penduduk setempat menyebut kadara berarti arak ke gunung. Penduduk Tidore mengenal dua arat tempat bermukim, yakni kadara dan kalau, yang mengantarai adalah jalan poros yang mengelilingi pulau Tidore. Kadara berarti rumah yang sebelah atas dari jalan raya dan kalau adalah rumah yang berada ke arah pantai atau laut. Antara penginapan Seroya dengan rumah Muhyiddin diantarai oleh jalan poros tersebut, penginapan Seroya kalau dan rumah panglima kadara, ini berarti bila kami hendak mengunjungi penglima, kami harus berjalan agak mendaki. Tipologi tanah pemukiman di Tidore pada umumnya tidak rata, pantai langsung gunung.

Sebelum kami berkunjung, terlebih dahulu kami memberitahukan melalui telepon. Kami memberitahukan bahwa kami sudah tiba di Tidore jam satu siang dan sekarang menginap di Seroja. "mau karumah sekarang? ... Saya...". Jawaban berda bertanya sang panglima kayaknya kurang terlalu respek, namun diakhir perkataannya ada kata saya. Saya untuk bahasa setempat dalam berkomunikasi berarti ya, atau setuju. Sama dalam sebahagian bahasa Bugis, ba. Berarti sang panglima setuju.

Kami pun berlima ke rumah beliau, tak lupa membawakan buah tangan yang kami bawa dari Makassar, buah kurma dan parsel yang kami beli di pelabuhan Bastiong tadi pagi. Perjalanan yang agak mendaki kerumah sang panglima hanya di tempuh lima menitan, menelusuri jalan yang bersih dan penataan bunga yang berwana warni, hembusan angin laut, pemandangan pantai, laut, dan dari kejauhan tampak pulau Mare dan pulau Halmahera, menambah kekaguman kami kepada sang 
pencipta dan sang pemilik alam semesta.

Rumah penduduk pada umumnya tidak bertingkat, dengan teras depan dan samping yang luas serta tanaman bunga, baik yang di tanam dalam pot bunga maupun yang ditanam langsung ke dalam tanah. "bersihnya kampungya orang di, saya jadi malu buang sampah", celoteh salah seorang tim kami yang baru kali ini menginjak dan menyaksikan betapa bersihnya kampung ini, Tidore. Kamipun sampai di rumah sang panglima, rumahnya cukup sederhana, mempunyai teras depan dan samping yang luas, menghadap kalau. Di teras rumah panglima kami menyaksikan beberapa bubungan rumah, melihat dengan jelas laut dan pulau Mare serta pulau Halmahera dari kejauhan.

Sampai di rumah panglima kami memberikan salam, sang panglima sudah menunggu di ruang tengah, beliaupun mempersilahkan kami masuk, beliau ke ruang tamu menyambut kami. Beliau masih sakit, sudah empat tahun beliau sakit strok, jadi beliau duduk di atas kursi roda, untung beliau masih baik diajak komunikasi. Kami satu persatu bersalaman dengan beliau. Kami duduk di kursi tamu, pembicaraan cukup lancar, maklum kami sudah beberapa kali diantar oleh beliau saat beliau masih sehat, dua tahun yang lalu saat kami datang terakhir kali, beliau sudah sakit, dan istri beliaulah yang mengantar kami.

Sesekali sang panglima menanyakan teman-teman dari Litbang yang pernah bertemu dengan beliau. Semua masih terpatri dalam memorinya. "maaf ini pak Idham, ibu tarada di rumah, pigi arisan" ujar panglima di sela-sela pembicaraan kami yang begitu hangat. Ternyata ini alasan kenapa saat kami menelpon beliau, beliau setuju namun kata-katanya nada bertanya, karena dia hanya sendirian di rumah tidak ada istrinya yang akan membuatkan minuman. "tidak ada apa-apa pak, kami ke sini hanya mau bersilaturrahim dengan bapak, sekaligus meminta kesiapan ibu untuk mengantar kami”.

Ternyata panglima sudah menghubungi orang-orang yang dianggap bisa membukakan naskahnya. Demikian halnya dengan istrinya bersedia untuk membantu mengantar kami ke pemilik naskah. Alhamdulillah. Di akhir pembicaraan, kami pun disuguhi teh dan kue. Sambil menikmati teh, sang panglima pun menelpon oto yang akan mengantar kami dalam penjelajahan besok. Setelah sepakat waktu, arah rumah tujuan, dan kendaraan yang akan mengantar kami besoknya, kami kembali pulang ke Seroja.

Bibir laut tepat di bagian belakang Seroja, di sini dibangun ruang pertemuan di atas laut, ada juga bangunan menonjol ke laut menyerupai dermaga. Selain itu di sini terdapat kolam renang kecil yang agak dangkal yang bersambung dengan kolam renang tanpa batas, laut dalam. Sepulang dari rumah panglima sore itu, kami menyempatkan mandi untuk menghilangkan kepenatan, semoga dengan berendam di air laut kebugaran kembali pulih. Kami semua bergembira, menikmati pemandangan yang luar biasa, sesekali dari kejauhan tampak perahu besar dan kecil melintas di tengah 
lautan, diantara pulau Halmahera, Tidore dan Mare. Di sepanjang pantai pun banyak masyarakat yang turun mandi, beberapa anak-anak berenang mendekati kami, mereka mau kenalan. Keramahan anak-anak ini menambah akan kebetaan kami nantinya di Tidore.

Namun naas bagi salah seorang di antara kami, Iwan. Dia tiba tiba menjerit, ternyata di tengah kegirangannya, ia menginjak bulubabi. Bulubabi semacam binatang laut yang ada di sela-sela karang. Saat terganggu, diinjak misalnya, maka dia akan menusuk menembakkan bulu-bulunya. Ada 11 tembakan di kaki Iwan, sangat perih. Abu Muslim berusaha menolong dengan cara mencungkil dan mencabut duri dari tapak kaki Iwan, namun tak bisa. Salah seorang petugas penginapan berseru agar kami mencari gaba untuk dipukulkan. Gaba adalah pelepah daun rumbia. Dimana kami akan mendapatkan gaba, kami orang baru. Tidak ada. Obat yang kedua adalah dikencingi. Itulah obat tradisional yang diwariskan secara turun temurun.

Apa hubungannya gaba dan air kencing untuk mengobati tusukan bulubabi? Ternyata ini mengusik pikiran Abu Muslim. Secara diamdiam Abu Muslim men-search seluk beluk bulubabi di internet. Akhirnya diketemukan bahwa bila duri bulubabi menusuk seseorang, maka bulubabi itu harus dihanjurkan dengan jalan memukul-mukul. Jadi bahan apapun bisa jadi obat penawar yang penting benda padat dan tumpul yang dipakai memukul untuk meremukkan bulubabi tersebut. Biar bukan gaba juga bisa. Sekarang cari batu untuk memukul kaki Iwan. Sakit memang, namun setelah dipukul sakitnya berkurang, dan akhirnya tidak terasa lagi.

Tiba saatnya makan malam, untung kami berpengalaman menginap disini. Makan malam harus dipesan kepada pemilik peginapan siang harinya, supaya mereka dapat belanja mempersiapkannya. Kalau tidak pesan makan malam, resikonya harus naik bentor ke pasar cari makan. Itu yang dialami beberapa tamu, mereka bertanya dimana pesan makan malam, kami katakan kami sudah memesannya tadi siang. Sambil makan, kami tetap bercanda sambil mengerjain Iwan, bagaimana saat dia tanpa sengaja menginjak bulubabi dan bagaimana reaksinya di atas speed saat speed yang kami tumpangi bermaslah dan memaksa kami pindah speed. Kedua kejadian itu begitu cepat, hanya berselang enam jam, dan membuat Iwan agak trauma di Tidore.

Setelah ishoma, kami berkumpul di belakang penginapan, menikmati terangnya bulan purnama, mendengarkan desiran ombak, menyaksikan lampu-lampu kapal yang lalu lalang. "maha suci Engkau ya Allah yang menciptakan semua ini, ma khalaqta hadza bathilan, semoga kami termasuk hamba yang tahu bersyukur atas nikmat-Mu", hanya itu yang tersirat dalam hati kami, semoga kesyukuran atas nikmat-Nya mengantarkan kami dalam tidur pulas malam ini.

Setengah delapan, pagi setelah sarapan tentunya. Juru kamera mempersiapkan segala kebutuhan pemotretan, kami menuju rumah panglima. Dilengkapi dua kamera 
dan dua tripot serta asesori lainya, seperti kabel, kain, kabel, dan tak lupa borang naskah. Kami menuju ke rumah panglima. Istri panglima, Nur Yusuf dan panglima sendiri sudah menunggu kami. Idham langsung masuk ruang tamu, sementara anak muda biar di teras biar leluasa bergurau sambil menikmati pemandangan. Pemberangkatan agak telat satu setengah jam, oto yang sudah dipesan masih di Rum, setelah menunggu agak lama ada informasi oto tersebut ada masalah, jadi tidak dapat mengantar kami. Panglima kecewa dan agak marah bicara di telpon. Itu bisa kami maklum karena panglima orangnya disiplin, dan kami sudah dijanji difasilitasi beliau.

Kita pun berinisiatif untuk mencari kendaraan lain. Berarti kita ke jalan poros arah kalau. Namun sebelum itu, panglima meminta istrinya untuk dibelikan pulsa, dengan cekatan sayapun memberikan istrinya uang pembeli pulsa, walaupun panglima mengatakan tak usah, namun pulsanya habis kan untuk kami. Tak lupa kami pun menyodorkan ke panglima satu uang informan dan satu uang naskah, berikut istrinya pun kami memintanya untuk tanda tangan satu uang naskah dan satu uang informan. Itulah cara kami menjaga guide kami, yang sebenarnya tanpa itu pun kami akan tetap dibantu karena sudah ada hubungan yang baik yang kami bangun sejak lama.

Mencari kendaraan di daerah seperti Tidore, jangan bandingkan akan sama mudahnya mencari kendaraan di kota. Setelah ibu Nur Yusuf mendatangi keluarganya, kami pun mendapatkan mobil Avansa carteran. Kami diantar ke rumah
Daud Hamisi di kelurahan Dowora, sekitar 10 menit perjalanan dari Soasio.

Istri panglima yang duduk di samping supir turun terlebih dahulu, langsung masuk ke rumah pak Daud Hamisi, menyusul kami di belakangnya. Pak Daud sudah menunggu kami. Kami langsung menuju ruang tengah, sementara tim yang lainnya di ruang tamu. Pertama-tama kami mengutarakan maksud kedatangan kami, dan juga Nur Yusuf menjelaskan dalam bahasa Tidore, Pak Daud pun tidak keberatan. Kalau di rumah pak Muhiddin bisa difoto, maka disini juga bisa, kata beliau. Naskah pun diangkat dari lemari. Naskah beliau ditaruh dalam lemari ruang tengah, tidak dibungkus seperti naskah yang kami temukan sebelumnya. Ini berarti sang pemilik naskah tidak mensakralkannya. Negosiasi selesai, saatnya bereaksi. Setelah diberi kode, dengan cekatan, Abu Muslim, Sadli, Nur dan Iwan memasang kamera di teras, setelah sebelumnya kami meminta izin untuk memotret naskah di teras rumah agar lebih terang. Sambil mengisi borang, yang lain memotret naskah yang sudah dibersihkan dan dikode, tim negosiasi tetap ngobrol dengan pak Daud dan ibu Nur Yusuf. Dari pembicaraan kami, beliau orangnya cukup terbuka, dan menanyakan asal daerah kami masing-masing. Dia mempunyai tujuh orang anak, dan empat diantaranya kawin dengan orang di luar Tidore, salah satunya ada yang anaknya tentara yang kawin dengan orang Mandar, maka tambah akrablah kami, ada hubungan emosional. Dengan bangga dia memanggil anaknya yang tentara, 
beristrikan orang Mandar untuk datang menemui kami. Anaknya pun datang ngobrol dengan saya, tenyata dia pun pernah bertugas di Polewali. Urusan semakin lancar.

Tanpa terasa digitalisasi naskah sudah selesai, teh yang dihidangkan pun sudah ludes. jam manunjukkan jam 12 siang, perut sudah menagih kebiasaannya. Kami pamit dan bersyukur dopu kepada pemilik naskah, kami ke mobil, dan sekarang kita ori oyo (ayo makan). Kami menuju rumah makan ikan bakar milik orang Jawa, inilah satu-satunya rumah makan ikan bakar di Tidore. Kami cukup menikmati makan siang hari ini, tak lupa kamipun memesankan ikan bakar untuk panglima.

Makan siang usai, kami kembali melakukan menjelajahan naskah bersama ibu Nur Yusuf, istri panglima, kali ini kami akan ke rumah Zakariah, kami masuk-keluar kampung, ternyata istri panglima juga tidak tahu alamat yang jelas, setelah lama mencarinya, diketahui bahwa pak Zakariah telah meninggal dua bulan yang lalu, anak lelakinya yang kemungkinan besar menyimpan naskahnya tidak ada di Tidore, dia ada di Ternate. Sekedar informasi, apabila pemilik naskah meninggal, maka secara otomatis naskah tersebut menjadi milik anak laki-laki, perempuan dilarang menyentuh naskah. Apabila anak laki-laki tidak mampu menjalankan/menyimpan naskah, maka naskah tersebut dikembaliikan ke guru thariqatnya.

Dari Dowora kami menuju Gamtufkange, kami menuju rumah pak Hasanuddin. Hasanuddin bekerja sebagai satpol Pamong Praja, awalnya agak sungkan untuk memperlihatkan naskahnya, namun negosiasi yang alot dan rayuan ibu Nur Yusuf, naskah pun keluar dari lemari penyimpanan. Naskah dalam keadaan terbungkus kain putih yang dibordir, kain tersebut adalah bendera tarikat yang disebut panji putih. Saya meminta izin membukanya, setelah suasana mencair, kamipun dipersilahkan mendigitalkan dengan syarat naskah harus dialas dan tidak boleh dipotret di luar rumah, harus dipotret dalam rumah. Karena siang hari dan pencahayaan lampu tidak memadai, pasti tidak masimal hasilnya, ada bayangan, tapi tak apa yang penting bisa difoto. Ada beberapa naskah tua dengan alas naskah kertas Eropa, dan yang lainnya naskah tua dengan alas kertas lokal bergaris. Naskah Hasnauddin adalah milik orang tuanya yang juga pernah menjabar kadhi dan Imam Soasio ditahun 1960-an. Naskah pun selesai dieksekusi, kami pulang setelah berbasa basi dengan tuan rumah. Kembali ke penginapan, kami capek keliling seharian, namun kelelahan itu terbayar dengan hasil yang kami peroleh hari ini. Tanpa diminta, ibu Nur Yusuf meminta kami untuk jalan mencari naskah malam ini. Mau tidak mau, suka atau tidak suka kami harus mengiyakan, walau kami tahu semua anggota tima sangat lelah, kami mengiyakan mumpun ada yang mau mengantar. Disepakati kami akan dijemput di penginapan setelah shalat Magrib.

Pada saat kami makan malam, pak sadly dan supir yang antar jemput kami sudah nongol di penginapan. Pak Sadly, ini Sadly pakai y, berarti pak supir, kalau Sadli pakai i, itu berarti tim peneliti. Pak 
sadly cukup ramah dan orangnya disiplin, tepat waktu. Pak Sadly pun harus menunggu kami, ternyata pak Sadly adalah kemanakan dari ibu Salma, pemilik penginapan. Kami siap dengan segala peralatan yang dibutuhkan, kami naik mobil menuju rumah Nur Yusuf mentuk menjemputnya. Rumah yang pertama kami kunjungi adalah rumah pak Ridwan, dia marga Dano. Idham dan ibu panglima turun mobil untuk bernegosiasi, sementara yang lainnya tetap menunggu di mobil. Kami dipersilahkan masuk oleh istri pak Ridwan, saat kami duduk di ruang tamu, pak Ridwan keluar dari kamarnya. Setelah lama bernegosiasi, agaknya kami tidak akan berhasil membujuknya, pak Ridwan masih sangat memegang wasiat leluhurnya, tidak boleh memperlihatkan naskahnya kepada yang bukan semarga dengan beliau, apalagi kami pendatang dan belum masuk thatiqat beliau. Untuk mengurangi rasa kekecewaan saya, saya pun diantar pak Ridwan ke ruang wiridan. Di Tidore, bagi penganut thariqat, ada ruang khusus berupa kamar untuk wirid yang diperuntukkan untuk kominitasnya, selain itu ada kamar puji, kamar yang diperuntukkan untuk pribadi tuan rumah dalam berwirid, semacam tempat berkhalwat. Di kamar wirid ini tidak terlalu luas, sekitar $4 \mathrm{~m}$ x 5 $\mathrm{m}$, beralaskan karpet dan beberapa sajadah. Di belakang pintu masuk terdapat meja. Di atas meja terdapat tiga kotak anyaman bambu yang berisi panji-panji dan naskah. Saat saya dan pak Ridwan keluar dari kamar, di depan kamar wirid terdapat lemari kayu yang mana di atas lemari kayu tersebut terdapat peti kayu yang ukurannya cukup besar, dan menurut pak Ridwan semua naskah peninggalan leluhurnya ada dalam peti tersebut. Pak Ridwan menginformasikan, kalau peneliti ingin melihat naskah tersebut namun tak boleh pegang-pegang, hanya boleh liat-liat, peneliti dapat datang pada saat acara wiridan yang setiap malam Sabtu. Marga Dano punya jadwal rutin wirid di setiap malam Sabtu, ujar pak Ridwan. Sangat disayangkan kami tak dapat melihat apalagi memotretnya. Pak Ridwan menyarankan kami agar pergi ke rumah saudaranya yang bernama Sofyan. Kami pun pamit untuk pergi ke rumah pak Sofyan.

Kami pun bergegas menuju rumah Sofyan. Rumah pak Sofyan berderetan dengan rumah pak Ridwan, hanya diantarai beberapa rumah. Rumah pak Sofyan cukup besar dengan pekarangan yang asri, apalagi di taman depan disinari remulan dan lampu taman. Kali ini hanya saya dan supir yang turun, kelihatannya ibu panglima juga sudah mulai ragu. Kami dapat mepahami karena beliau beda marga, marga panglima adalah Jawa Turu, sementara pak Sofyan adalah Dano. Cukup lama peneliti dan pak Sadly mengetuk pintu, bahkan pak Sadly berinisiatif untuk mengetuk pintu samping. Peneliti tetap di pintu utama. Akhirnya ibu tuan rumahpun membukakan pintu dan menanyakan siapa kami. Saya masuk sendirian di ruang tamu. Ruang tamu ini cukup besar dengan perabot yang lumayan wah untuk ukuran Tidore. Tak lama berselang pak Sofyan muncul dari ruang tengah. Kami pun berdialog, semua jurus telah dikeluarkan peneliti, namun tak dapat 
meluluhkan hati sang tuan rumah. Tuan rumah, pak Sofyan berdalih bahwa naskah itu tak dapat dilihat oleh sembarang orang, ada syarat baru bisa pegang, kalau masuk tariqat pun ada kelas-kelasnya. Kami takut poso, kata Pak Sofyan. Poso bermakna kualat, dapat kutukan. "yang saya takutkan bukan hanya bapak yang kena poso, keluarga kami pun bisa kena, jadi maaf beribu maaf kami tak bisa membuka lemari naskah kami untuk diperlihatkan kepada orang lain", ujar pak Sofyan menutup pembicaraan.

Kelihatannya malam ini tim peneliti lagi sial, tak ada yang mau membukakan naskahnya.

Selanjutnya ibu panglima mengantar kami menuju rumah keluarganya yang disinyalir ada naskah, akan tetapi kepala keluarga lagi keluar daerah, jadi tidak mungkin kami dapat diperlihatkan oleh keluarganya yang lain, apa lagi yang ada di rumah adalah perempuan, itu pantangan. Cukuplah sudah kesialan kami malam ini, sudah tiga rumah yang kami masuki, namun semua tidak ada naskah yang dapat diperlihatkan. Oke, kita cabut, langsung ke penginapan? Jangan dulu kita jalanjalan mumpun ada yang mengantar. Kita kelilingi kota pemerintahan Kota Tidore, dari kejauhan ada pantai Tugulupa, pantai ini cukup ramai dikunjungi masyarakat Tidore, khususnya malam minggu, namun kalau malam Jumat tempat ini agak sepi, maklum banyak haroa (acara ritual wiridan di rumah-rumah). Kami pun ke Tugulupa untuk minum minum minuman khas Tidore, guraka. Guraka adalah munuman dari larutan gula merah, jahe, dan kenari yang ditabur di atasnya.
Semacam sara'ba di Makassar. Tapi jangan pelesetkan, bisa-bisa menyebutnya air durhaka. Air guraka hanyat sangat cocok bila didampingii pisang goreng beserta kacang tanah goreng.

Di Pantai Tugulupa, di samping menikmati air guraka bersama pisang goreng, kami pun menikmati ombak yang samar-samar berkejar-kejaran diterpa sinar rembulan. Kami saling bergurau, antara tim peneliti dan ibu panglima serta pak Sadly ikut berbaur dengan kami, tak ada lagi sekat. Sambil minum guraka, kesempatan itu juga digunakanuntuk menelpon keluarga, soalnya sudah sakit kepala, sudah hampir satu minggu di rantau. Tak lupa kamipun memesankan air guraka dan pisang goreng untuk panglima. Setelah menikmati indahnya pantai Tugulupa, jadi jangan lupa ya, sesuai nama pantainya yang indah, kami kembali ke penginapan, dan selanjutnya pak Sadly mengantar ibu panglima ke rumahnya. Sebelum berpisah kami pun janjian untuk dijemput besok pada jam 8 pagi untuk pergi ke Tugiha. Walupun malam ini tak mendapatkan naskah, namun kami mendapatkan pengalaman dalam pengembaraan di Tidore, kami banyak tahu tentang cetita-cerita tentang Tidore dari ibu panglima dan pak Sadly.

Malam ini, setelah menikmati air guraka di Tugulupa, kami tidak langsung beristirahat, akan tetapi kami masih menyempatkan bersenda gurau di teras belakang penginapan. Di bawah cahaya rembulan, menghadap kalau akan tampak indahnya laut berikut ombaknya yang tiada henti bergerak, dari 
kejauhan tampak dengan samar pulau mare dan pulau Halmahera, menghadap kadara tampak gunung Tidore tang berdiri kokoh. Di tengah sendagurau kami, kami pun kadang memutar ulang pembicaraan pak Sadly tentang yang mistik-mistik di Tidore, termasuk di malam Purnama di dekat pantai Tugulupa, di atas jam 10 malam akan selalu ada beberapa tapak kaki menuju kadara. Namun sampai sekarang tidak diketahui siapa yang punya tapak kaki tersebut. Namun bagi masyarakat sekitar itu sudah biasa. Termasuk cerita pak Sadly bahwa dua tahun yang lalu ada anak-laki-laki yang disunat secara gaib. Malam sudah larut, kami pun ke bilik masing-masing.

Seperti biasanya, pagi ini kami dijemput pak Sadly saat kami sarapan. Itu yang saya suka dari pak Sadly, seorang supir yang disiplin. Kamipun tim peneliti ke mobil beliau untuk menjemput ibu panglima sebelum ke Tugiha. Setelah menjemput ibu panglima, mobilpun melaju.

Sesampai di Tugiha, kami diajak masuk rumah yang cukup sederhana. Kali ini tim dipersilahkan turun dari mobil dan menuju rumah. Akan tetapi anggota tim hanya di luar, di teras. Sementara saya dan ibu panglima masuk ke ruang tamu. Di atas meja sudah ada dua bungkusan kain putih. Ibu panglima memberitahu bahwa pemilik sudah ditelpon oleh bapak (panglima). Kami baru saja duduk, pak Abdul karim muncul dari dalam dan menyapa kami. Setelah negosiasi yang cukup singkat, naskah pun siap dieksekusi. Dua buah bungkusan naskah milik Abdul Karim adalah warisan dari orang tuanya, orang tua dari Abdul Karim adalah murid dari kakak Muhiddin (panglima) yang bernama Muhammad Thahir. Pak Abdul Karim mengaku bahwa dirinya baru kelas 3 dalam hal thariqat, jadi baginya hanya bungkusan pertama yang dia bisa buka, sementara bungkusan yang kedua, peninggalan orang tuanya yang tidak diperbolehkan baginya untuk membuka apalagi membacanya. Untuk bungkusan yang kedua, kelihatannya beliau keberatan kalau peneliti membukanya, namun atas negosiasi yang alot, naskah bungkusan kedua pun akhirnya dapat kami digitalkan.

Informasi pak Abdul Karim mengatakan bahwa saudara sepupunya yang bernama Usman, juga punya naskah, kami pun memintanya untuk mengantarkan saya ke rumah sepupunya tersebut. Alhamdulillah, kakak sepupunya tersebut ada di rumahnya, namun naskah itu sudah kami potret beberapa tahun yang lalu. Saat kami meninggalkan rumah sepupunya, pak Usman memperingatkan pak Abdul Karim dalam bahasa Tidore yang dicampur bahasa Indonesia. Dari peringatan itu, tersirat kalimat "jangan kau urus yang begituan, perlihatkan sama torang lefo-lefo, kau bisa sama Muhiddin, bisa-bisa ko juga strok". Dari peringatan pak Usman itu semakin memperkuat pemahaman kami bahwa, pada umumnya masyarakat Tidore mengenal poso kalau membuka atau membaca lefo-lefo bagi yang belum pantas. Kami diliputi rasa bersalah, apakah betul pak Muhiddin yang selama ini membantu kami, kami anggap sebagai orang tua sendiri, mengantar kami saat beliau masih 
sehat, apa benar beliau terserang stroke karena kena poso? Karena keberaniannya memperlihatkan naskah kepada kami yang bukan orang Tidore dan belum dibaiat? Tapi pak Muhiddin sendiri, pada suatu kesempatan pernah berkata, orang poso bukan karena buka lefolefo, tapi itu memang penyakit, banyak juga orang tidak pernah buka lefo-lefo tetapi dia sakit dan meninggal". Untunglah panglima berpendapat seperti itu, ya maqamnya sudah tinggi. Terima kasih panglima.

Setelah selesai pemotretan di Tugiha, kami pun kembali ke Soasio dan langsung ke rumah makan ikan bakar. Kami semua menikmati lezatnya ikan bakar Tidore. Tak lupa kamipun pesankan ikan bakar untuk pak Panglima. Saya sendiri bersama ibu panglima bercerita di ruang makan. Untuk lebih mengakrabkan diri dengan ibu panglima, saya belajar bahasa Tidore, seperti.

$\begin{array}{ll}\text { satu } & \text { remoi } \\ \text { dua } & \text { molofo } \\ \text { tiga } & \text { range } \\ \text { empat } & \text { raha } \\ \text { lima } & \text { ramtoha } \\ \text { enam } & \text { rora } \\ \text { tujuh } & \text { tumdi } \\ \text { delapan } & \text { tufkange } \\ \text { sembilan } & \text { sio } \\ \text { sepuluh } & \text { nyoboi } \\ \text { sebelas } & \text { nyoboi sermoi } \\ \text { tigabelas } & \text { nyoboi malofo } \\ \text { empatbelas } & \text { malofo sermoi } \\ \text { limabelas } & \text { malofo yamolafo } \\ & \\ \text { Apa } & \text { mega } \\ \text { Siapa } & \text { nage } \\ \text { Kapan } & \text { fio } \\ \text { Dimana } & \text { kabe } \\ \text { Berapa } & \text { pirai }\end{array}$

$\begin{array}{ll}\text { Bagaimana } & \begin{array}{l}\text { gatebe } \\ \text { iya ta }\end{array} \\ \text { Kesana } & \text { ino kere } \\ \text { Mari sini } & \text { ija } \\ \text { Harga } & \text { oyo } \\ \text { Makan } & \text { yuru } \\ \text { Minum } & \text { tagi } \\ \text { Pergi } & \text { wako } \\ \text { Pulang } & \text { ino } \\ \text { Ayo } & \text { ronga }\end{array}$

Selain itu, kami juga belajar sejarah Soasio; Soasio adalah ibukota kaesultanan Tidode. Di Soasio sampai sekarang pun masih berdiri kedaton dan masjid kesultanan yang disebut Sigilamo. Soasio artinya terdiri atas dua kata, yakni soa yang berarti rumah atau kampung atau komleks, dan sio artinya Sembilan. Jadi soasio artinya Sembilan kompleks perumahan. Adapun kesembilan kampung yang mendiamo soasio, yakni: 1) Soa Jawa, 2) Soa Jaba, 3) Soa Mbelo, 4) Soa Mafu, 5) Soa Kolodi, 6) Soa Rora, 7) Soa Cina, 8) Soa Falailuku, dan 9) Soa Raimdoya.

Adapun marga yang mendiami Soasio ada enam, yakni:

1. Marga Dano

2. Marga Pabanyo,

3. Marga Jawa Konora

4. Marga Jawa Turu

5. Marga Tughubu, dan

6. Marga Ngofa.

Demikian halnya dengan imam masjid kesultanan (sigilamo). Terdapat enam imam yang bergantian dalam setiap bulannya. Imam tersebut hanya bertugas dua bulan dalam setahun. Keenam imam tersebut juga mewakili marga dan kampung yang ada. Adapun keenam imam tersebut, yakni:

1. Imam Jawa Turu

2. Imam Tughubu 
3. Imam Fabanyo

4. Imam Soasio (mewakili dayado, Doa, Konora, dan Buku)

5. Imam Jawa Konora, dan

6. Imam Ngofa (kesturunan Sultan)

Setelah selesai menikmati makan siang kami kembali ke penginapan, tidak ada perburuan naskah sore itu. Kami hanya memanfaatkan waktu bersantai sambil berenang di pantai.

Sesuai kesepakatan tim bahwa hari Jumat adalah hari terakhir perburuan naskah. Dua hari sebelumnya kami juga sudah mengatur segala sesuatunya dengan salah seorang tokoh masyarakat Toloa, Pak Khaeruddin, beliau fam Fabanyo. Pak Khaeruddin juga pernah membantu kami dalam penelusuran naskah dua tahun yang lalu, selain itu beliau adalah salah seorang pemilik naskah. Beliau akan mengantarkan kami ke pulau Maitara. Pada dua tahun yang lalu kami pernah ke Maitara namun tidak memperoleh naskah. Pulau Maitara adalah pulau kecil antara Pulau Tidore dangan Pulau Ternate. Pulau ini cukup terkenal karena gambarnya ada pada uang seribu rupiah.

Kami tim digitalisasi naskah berangkat dari Seroja menuju Toloa, kediaman pak Khaeruddin, dan ternyata pak Khaeruddin sudah menunggu kami, kami pun bersama beliau langsung cari oto untuk menuju pelabuhan Rum. Dari pelabuhan inilah speed sewaan banyak menawarkan jasa, baik ke Maitara, Ternate, Sofifi, dan pulaupulau lainnya. Untuk mengefektifkan waktu, kami bersepakat untuk mencarter saja, kalau sewa normal
Rp 5000,- dan kalau carter hanya Rp 50000,- sekali jalan. Dari pelabukan Rum (Tidore) menuju pelabuhan Doedoe (Maitara) hanya ditempuh sekitar dua menit. Cukup dekat.

Pulau Maitara terdiri atas empat kelurahan/desa, yakni Maitara Selatan, Maitara Tengah, Maitara Utara, dan Maitara Induk. Pelabuhan Doedoe sendiri berada di Maitara Tengah. Dari pelabuhan kami berbelok kearah kiri menuju Maitara Selatan. Karena merasa masih agak pagi, kami berjalan kaki menelusuri jalanan yang berbatu, belum pernah ada pengaspalan di sini, sebahagian dibeton. Walupun masih pagi, kami pun kelelahan karena agak jaun sekira 30 menit jalan santai, disamping matahari mulai panas, juga karena kami semuanya membawa peralatan. Setelah penunjuk jalan kami bertanya beberapa kali, kami pun sampai di rumah pak Imam Desa Maitara Selatan, Zakariah Usman fam Marajabessi. Hanya Idham dan pak Khaeruddin yang menuju ke rumah pak imam, sementara anggota tim yang lain menunggu dan beristirahat di pos ronda. Kami berdua sampai di rumah pak imam, namun pak imamnya baru saja keluar. Di rumah hanya ada istri dan anak pak Imam, dari mereka kami diberitahukan bahwa pak Imam pergi melayat salah seorang warganya yang meninggal dunia, tidak jauh dari rumahnya. Pak Khaeruddin berinisiatif menyusul pak Imam untuk mecari informasi kapan mayat tersebut dikuburkan, dan sekaligus menemui pak Imam. Idham pun harus menunggu ditemani anak pak Imam. Beselang 40 menit pak Khaeruddin kembali dan mengatakan bahwa sebentar lagi pak 
imam akan kembali karena sekarang, mayatnya sedang dimandikan. Kami pun bertiga menunggu pak imam, sementara anggota tim yang lain masih di pos ronda.

Menunggu adalah hal yang membosankan, demikian yang kami rasakan, termasuk anggota tim yang ada di pos ronda. Sesekali anggota tim mengirimkan sms mempertanyakan apa yang terjadi di rumah pak imam, meragukan apa akan dapat bertemu pak imam, termasuk sms memberitahukan bahwa mereka di pos ronda oleh masyarakat anggota tim dikira penjual keliling, beberapa masyarakat datang menanyakan jualan yang dibawa anggota tim peneliti.

Tepat jam 11, dari kejauhan pak imam pulang, itu kami yakini karena pak imam memakai pakain kebesarannya, gamis panjang terbuka bagian depan berwarna hijau muda menyolok. Sang imam menyapa kami yang lagi duduk di teras depan rumahnya dan mepersilahkan masuk ke ruang tamu. setelah pak Kheruddin berbasa basi, sang penelitipun pengutarakan maksud ke Maitara menemui pak Imam. Dengan bahasa Indonesia yang pas-pasan, pak imam kelihatan sangat gelisah, raut mukanya pucat. Kadang pak Khaeruddin mengalihkan pembicaraan, sekitar 15 menit kami bernegoisasi, pak imam berkata: kami sangat takut kalau apa yang kami punya dilihat orang lain. Kalau tidak bisa, apa boleh buat, kami pasrah. Idham dan Khaeruddin pun pamit pulang dan menemui anggota tim yang sedari tadi menunggu di pos ronda tanpa kepastian.
Pertanyaan yang muncul dari anggota tim saat selesai negosiasi adalah bagaimana, bisa atau tidak? Sulit jawabku. "kita pulang kembali ke pelabuhan, mau naik ojek atau jalan kaki? Tanya Khaeruddin. Kalau ada ojek tak usah jalan kaki, tim sudah kelelahan, panas matahari, jauh, dan juga lapar. Sudah agak lama menunggu ojek, namun tak ada yang lewat, bila ada pengendara yang lewat, kami pun memesan agar ada ojek yang datang mejemput, akan tetapi semua sia-sia, di sini tidak ada oto sewa. Tidak lama kami berjalan dalam kepasrahan, tiba-tiba ada mobil open cap bertanya tujuan kami dan menwarkan jasa untuk kami tumpangi. Alangkah gembiranya kami, seperti pengembara kehausan yang menemukan setitik oase penghilang dahaga. Terlebih lagi kami bersyukur, kami digratiskan.

Kami pun tiba di pelabuhan Doedoe. Pemandu kami mengajak Idham ke Akebai, ibukota desa Maitara Induk yang jauhnya sekitar 3 $\mathrm{km}$ dari pelabukan Doedoe. Pak Khaeruddin meminjam ojek, jadilah pak Khaeruddin menjadi tukang ojek sementara membonjeng Idham. Kami sepakat, anggota tim yang lain menunggu di pelabuhan Doedoe sambil menunggu informasi selanjutnya dari tim negosiator. Jalanan ke Akebai cukup rusak, ada tanjakan dan penurunan. Kami tidak menyangka bahwa di sebelah pulau Maitara, penduduknya cukup padat. Pak Kaheruddin menemui beberapa keluarganya, menurut penuturan Pak Khaeruddin, di Akebai inilah nenek monyang berasal, fam Fabanyo. Kami memasuki rumah pak Alim Fabanyo, setelah negosiasi, pak Alim tidak keberatan apabila naskahnya 
didigitalkan. Idham pun bimbang, apakah naskah ini akan dieksekusi hari ini atau tidak? kalau dieksekusi bagaimana anggota tim yang lain apa sanggup? mereka sudah kelelahan, apalagi belum makan siang, disini tidak ada warung makan, masjid sudah tarhim, sebentar lagi jumatan. Tapi kalau tidak di eksekusi, kapan lagi kesini, itu pun apakah masih akan bersedia. Mumpun ada kesempatan, gunakanlah kesempatan itu. Idham menelpon anggota tim yang sementara menunggu untuk sesegera mungkin datang ke Akabai. Tanya sama tukang ojek, mereka pasti tahu.

Tidak berselang lama, anggota tim-pun tiba di rumah pak Alim. Anggota tim langsung beraksi, pasang tripod, dan foto naskah. Baru satu naskah yang didigital, azan masjid berkumandang, kami pun ke masjid yang tepat berada di depan rumah pak Alim, untuk melaksanakah shalat Jumat.

Masjid ini cukup bagus, dua tingkat. Akan tetapi yang menjadi pertanyaan buat kami, kenapa masyarakat yang datang shalat jumat hanya dua shaf? Menurut pak Khaeruddin, itu disebabkan karena pada umumnya penduduk bekerja di pelabuhan Rum dan pelabuhan Doedoe. Tapi setelah kami mengamati, banyak orang laki-laki yang berada di kampung Akebai, mereka tidak keluar, tapi mereka tidak melaksanakan shalat jumat, apa ada hubungannya dengan masalah syariat, thariqat, hakikat, dan ma'rifat sebagaimana yang banyak dalam naskah-naskah? Atau yang ke masjid adalah mereka yan g sudah baiat thariqat? Peduli amat, kami hanya datang mencari naskah, ibadah adalah urusan hamba dengan khalik.

Kami-pun melanjutkan pelaksanaaan pemotretan dalam keadaan perut keroncongan, jam sudah menunjukkan pukul 14, karena jumat dlaksanakan jam 13. Jam 14 waktu Maitara, berarti di Makassar sudah jam 13, dimana kami akan makan siang? Saya sangat sesalkan kami tidak membawa persiapan. Sebenarnya kami ada persiapan kua gabin di tas Iwan, akan tetapi tas tersebut tidak dibawa karena yang punya tas tidak ikut dalam kesempatan ini karena trauma saat penyeberangan dari Ternate ke Tidore beberapa hari yang lalu, saat kami baru datang di Maluku Utara.

Sebagaimana penduduk Indonesia pada umumnya, apalagi masyarakat pedalaman, bila ada tamu dan waktu makan tiba, tamu harus diberi makan apapun adanya. Itu juga yang dilakukan oleh Pak Alim, ternyata diam-diam istri pak Alim mepersiapkan makan siang hari ini. Alhamdulillah kami makan siang bersama tuan rumah di ruang makan. Tuan rumah meminta maaf karena hanya dapat menyajikan nasi putih dan ikan bakar, tak ada yang lain. Bagi kami ini sudah lebih dari cukup. Setelah makan siang, kami pun melanjutkan pendigitalan naskah.

Mencari kendaraan di daerah seperti ini amatlah sulit. Di jalan poros kami hanya menemukan satu ojek. Jadilah kami antrian, sambil menunggu ojek yang lain, atau ojek tersebut yang mondar mandir menjemput kami. Lagi-lagi kami bernisiatif jalan kaki. Tak seberapa jauh kami berjalan, ternyata disini ada tugu uang seribu rupiah, 
kamipun gunakan kesempatan tersebut untuk berfoto ria.

Cukup lama juga kami berjalan, penulis dan Pak Khaeruddin masih mencari naskah di Maitara Tengah, sementara anggota tim yang lain langsung ke pelabuhan Doedoe. Kami tiba di Rumah pak Imam Maitara Tengah, Syamsuddin Dano Arif, beliau sedang istrirahat sambil menunggu shalat Ashar. Setelah negosiasi, pak imam pun tidak keberatan bila naskahnya didigitalkan. Idham pun menelpon anggota tim yang sementara menunggu di Doedoe. Tak lama berselang anggota tim pun datang, karena memang sangat dekat, mereka datang dengan pakai ojek. Eksekusi naskahpun dilakukan di tengah kelelahan yang sangat, ngantuk yang tiada tara. Maaf anggota tim-ku. Kalian benar-benar bisa diandalkan. Setelah selesai kami pun berjalan kaki menuju pelabukan Doedoe dan selanjutnya menuju pelabuhan Rum dengan speed.

Di pelabubahn Rum, anggota tim naik oto langsung menuju Soasio, sementara Idham dan Pak Khaeruddin naik oto yang berbeda karena mereka berdua akan singgah di Toloa, di rumah Pak Kaheruddin untuk menyelesaikan administrasi yang belum sempat terselesikan dalam perjalanan. Terima kasih pak Kheruddin, bapak telah mengantarkan kami hari ini mengelilingi pulau Maitara, Pulau lengendaris uang seribu rupiah.

Di hari terakhir kami perlu mencari literatur di perpustakaan daerah (Kabupaten Tidore Kepulauan). Tidak banyak buku lokal disini, seperti daerah yang pernah kami kunjungi sebelumnya.
Di sana tak ada foto copy, namun atas pendekatan kepada pegawai perpustakaan, kami diizinkan memotret beberapa buku, adapun buku-buku yang sempat kami digitalkan, seperti buku karangan Des Alwi (2005), Widjojo (2013), Rosyidi (2009), Hanna (1996), R.Z. Leiressa (ed) (2001), Muhammad (2004), Abdulrahman (2002), Atjo (2008), Faaroek (Tth), Conoras (2015), Baay (2015), Asriani (2015), E.Katoppo (1957), dan lain-lain.

Malam harinya, kami tidak punya kegiatan, kami hanya persiapan untuk kembali ke Ternate besok pagi, kami hanya menikmati tidur lelap karena kelelahan yang tiada tara. Pagi harinya, setelah berkemas untuk ke Ternate, Idham sebagai negosiator, pergi menemui sang Panglima untuk minta pamit. Setelah itu kami semua ke pelabuhan Rum untuk menuju ke pelabuhan Bartiong. Di Ternate kami menginap di Grand Dafam, hotel yang cukup bergensi di Maluku Utara. Sampai jumpa kembali pada pengumpulan data berikutnya.

\section{PENUTUP}

Ada beberapa catatan perjalanan, penelusuran awal dan pencarian naskah klasik di Kabupaten Tidore Kepulauan Maluku Utara, antara lain:

- Masyarakat Maluku Utara (khususnya masyarakat Tidore) sangat terbuka bagi orang luar.

- Masyarakat setempat sangat mensakralkan naskah klasik (naskah tharikat) yang mereka wariskan secara turun temurun. Tidak sembarang orang dapat membuka dan membacanya, perlu 
pendekatan khusus untuk dapat mengaksesnya.

- Seberat apapun tugas dan tanggung jawab apabila dijalani dengan keikhlasan akan membuahkan hasil yang maksimal.

\section{Daftar Pustaka}

Abdulrahman, M. Jusuf. 2002. Kesultanan Ternate dalam "Jon Ngon Ka Dada Madopo Fangare Ngom Ka Alam Madiki. Manado: Media Pustaka.

Asriani, Sherly, dkk. 2015. Sejarah Masjid Sultan Moloku Kie Raha. Makassar: Pustaka Refleksi.

Atjo, Rusli Andi. 2008. Peninggalan Sejarah di Pulau Ternate. Jakarta: Cikoro Printing.

Baay, Muhammad Miftah. 2015. Mozaik Arsip Tidore Maluku Utara Sumber Naskah Kuno dari Di Arquivo Nacional Da Torre Do Tombo Portugal. Tidore: Badan Kearsipan dan Perpustakaan Provinsi Maluku Utara.

Conoras, Irmawaty (ketua). 2015. Khazanah Arsip Empat Kerajaan di Maluku Utara (Moloku Kie Raha dalam Catatan Arsip Bangsa Eropa. Jakarta: Kerjasama Badan Kearsipan dan Perpustakaan Provinsi Maluku Utara dan Arsip Nasional Republik Indonesia.
Des Alwi. 2005. Sejarah Maluku: Banda Naira, Ternate, Tidore dan Ambon. Jakarta: Dian Rakyat kerjasama dengan Yayasan Warisan dan Budaya Naira.

E.Katoppo. 1957. Perjuangan Kemerdekaan di Maluku Utara. Jakarta: Sinar Agape Press

Faaroek, M. Amin. Tth. Kilas Balik Kota Soasio Sebagai Pusat Pemerintahan Kesultanan Tidore dan Prospeknya (tidak diterbitkan)

Hanna, Willard A. 1996. Ternate dan Tidore: Masa Lampau Penuh Gejolak. Jakarta: Pustaka Sinar Harapan.

Muhammad, Sahril. 2004. Kesultanan Ternate: Sejarah Sosial Ekonomi dan Politik. Yokyakarta: Ombak.

R.Z. Leiressa (ed). 2001. Ternate Bandar Jalur Sutra. Jakarta: Yayasan AdikaryaThe Ford Foundation.

Rosyidi. 2009. Sejarah Hukum Eksplorasi Nilai, Asa, dan Konsep dalam Dinamika Ketatanegaraan Kesultanan Tidore. Malang: Universitas Negeri Malang.

Widjojo, Muridan. 2013. Pemberontakan Nuku: Persekutuan Lintas Budaya di Maluku-Papua Sekitar 1780-1810. Depok: Komunitas Bambu. 